\title{
Cultural Identity in Bahamian Art Music: The Expression of Four Bahamian Composers
}

\section{Carlton Leroy Wright Christine Gangelhoff ${ }^{1}$ The College of The Bahamas}

\section{INTRODUCTION}

The International Symposium on Composers of African and Afro-Caribbean Descent took place on Thursday, February 21, 2013 at The Harry C. Moore Library and Information Centre Auditorium, The College of The Bahamas, in Nassau, Bahamas.

This historic conference, coordinated by Christine Gangelhoff, Assistant Professor of Music, The College of The Bahamas, and Marlon Daniel, Music Director, Ensemble du Monde, was convened to engage musicians, composers, and scholars from all over the world in presentations, performances, and conversations about composers and performers of African and Afro-Caribbean descent. It was organized around the theme "Caribbean Art Music: An Unexplored Tradition".

This article is a transcription of the presentations delivered by participants of the session: Cultural Identity in Bahamian Art Music: The Expression of Four Bahamian Composers. Edward Bethel moderated the session, which featured Bahamian composers Cleophas Adderley, Audrey Dean-Wright,
Christian Justilien, and K. Quincy Parker. They discussed their work, focusing on their compositional style and how or if cultural identity is a strong component in their work. Featured compositions contain hyperlinks to audio/video-recorded examples.

Composer and moderator biographies are included, and more information may be found in the Symposium brochure.

\section{COMPOSER BIOGRAPHIES \\ K. Quincy Parker, Composer and Arranger}

Bahamian K. Quincy Parker is a composer, singer, guitarist, teacher and arranger. He began his musical journey in The Bahamas as a producer of hip hop in a MIDI studio owned and operated by Neil Symonette, one of the world's finest percussionists. Neil introduced him to jazz, which eventually led him to major in guitar performance at Oral Roberts University. After a semester at Oral Roberts University, he discovered his true calling composition. Quincy went on to earn an honours degree in Music Composition at Oral Roberts University, graduating as the

\footnotetext{
${ }^{1}$ Carleton Leroy Wright, Student \& Christine Gangelhoff, School of Communications and Creative Arts, The College of The Bahamas, P.O. Box N-4912, Nassau, Bahamas.

E-mail: cgangelhoff@cob.edu.bs

APA reference: Wright, C. L., \& Gangelhoff, C. (2013, February). Cultural identity in Bahamian art music: The expression of four Bahamian composers. Panel discussion at the International Symposium on Composers of African and Afro-Caribbean Descent, The College of The Bahamas, Nassau. The International Journal of Bahamian Studies, 19(2), 79-92. https://doi.org/10.15362/ijbs.v19i2.189
} 
Outstanding Composition Student in his year (along with his close friend and colleague Lydia Ashton) after winning the 20th century Composition Contest in his junior year. His dream was to write for film, but he has written numerous types of musical compositions: choral masses, oratorio, opera, symphony, concerti, and chamber music. He has written music for the film industry in The Bahamas as well as for both the Highgrove Singers and Bel Canto Singers, two of Nassau's best known vocal ensembles. One of the highlights of being a musician for him is being able to make music with his wonderful wife, Suzette.

\section{Christian Justilien,}

Assistant Professor (Band Director), The College of The Bahamas; Leader, AMBASAH (Jazz/Caribbean Band); Leader, Colours Entertainment \& Junkanoo Organization; Motivational speaker; Member, The C Force Chamber Ensemble.

Christian Justilien received a B.A. in Professional Music Studies from the Berklee College of Music in Boston, where he was the founding director of the Berklee Caribbean Ensemble, and a M.Ed. from the VanderCook College of Music in Chicago, Illinois. Justilien has created an educational website called Musicians \& Entertainers of The Bahamas.

$\mathrm{He}$ is actively involved in his community and projects geared towards the advancement of young people and the preservation of Bahamian culture. Justilien has produced four recordings of traditional Junkanoo music; three with Roots, and one more recently with his award-winning Junkanoo group, Colours.

His latest composition, "Bahama Islands Suite", written for C Force, vividly captures the discovery, historical events, and the spirit of the islands of The Bahamas.

\section{Audrey Dean-Wright, Associate Professor of Music, The College of The Bahamas}

Bahamian-born Audrey Dean-Wright has been a part of the fabric of music and culture of The Bahamas for over 40 years. She received her early piano training under the tutelage of Muriel Mallory, Meta Cumberbatch, and her mentor, E. Clement Bethel. She continued her music training at the Jamaica School of Music ${ }^{2}$, Kingston, Jamaica and Manhattan School of Music, New York, where she received the Bachelor and Masters of Music degrees. Mrs. Wright is one of The Bahamas' most prolific composers having composed over 250 pieces in a variety of genres, including compositions for solo voice, choir, flute and piano. Her works have been performed in the United States, the Caribbean, Europe, and most recently, in July of 2012, in China.

As the first non-American composer to be a featured composer with the Southeast African American Collegiate Festival, she has had the honour of conducting leading historically black university choirs in her original works. Her piano, choral and poetry compositions have been used as test pieces in the $\mathrm{E}$. Clement Bethel National Arts Festival ${ }^{3}$, The Bahamas. Mrs. Wright has written three books that are in use in the public schools in The Bahamas: Children Sing For Joy, a collection of 31 songs for children with accompanying CD; Audrey's Favourite Bahamian Songs and More, and The Young Pianist, a collection of piano pieces. Her collection of flute pieces, Flutescapes, with performance $\mathrm{CD}$, will be released in Spring 2014.

\footnotetext{
${ }^{2}$ Today it is known as the Edna Manley College of Visual and Performing Arts.

${ }^{3}$ The E. Clement Bethel Music Festival started in 1959 as the Bahamas Music Festival and is held annually.
} 
Cleophas Adderley, Executive Director, National Musical Heritage and Research, Ministry of Youth, Sports, and Culture.

Cleophas Adderley is a pillar in the cultural development of The Bahamas. He is currently Executive Director, National Musical Heritage and Research at the Bahamas Ministry of Youth, Sports and Culture. He is the founder and director of The Bahamas National Youth Choir, one of the foremost Bahamian cultural institutions that represents The Bahamas both nationally and internationally.

Adderley is a prolific composer. $\mathrm{He}$ has written for piano, pipe organ, choir, and solo voice. The Hal Leonard Corporation has published several of his works. He wrote the first Bahamian concert mass, Missa Caribe, and his opera Our Boys is the first grand opera to have been written and performed in the English-speaking Caribbean. $\mathrm{He}$ is the recipient of many awards for his work in the arts including the Distinguished Citizen Award and an award from the International Chapter of Alpha Kappa Alpha Sorority.

\section{Edward Bethel (session moderator), Director of Distance Education, The College of The Bahamas}

Edward Bethel, a doctoral candidate in Educational Technology at Concordia University, Montreal, Quebec, has had a 25year career in education at the secondary and tertiary levels. Music and culture has been a central theme in Mr. Bethel's life from a very early age, having participated in Junkanoo almost every year since 1970, the same year he had his first formal piano lesson. Since then, Mr. Bethel has played in bands, sung in, written for and directed choirs, and participated in theatre both onstage and backstage. Mr. Bethel has particularly fond memories of opportunities to perform nationally and internationally as a member of the Dicey Doh Singers, though the recurring highlight of his cultural life is "going to Bay" each Boxing Day and New Year's morning.

\section{TRANSCRIPT OF THE PANEL DISCUSSION}

\section{K. Quincy Parker}

So my name is Quincy Parker. I am the odd duck on this panel. They are extremely accomplished and very, very talented composers with history stretching back decades in some cases. My own history as a composer is relatively brief. I started writing art music in 1998, or 1999 maybe. And the reason that I did that was because as a ... Well, let's go back in time: as a 13-year old boy, I met a man named Neil Symonette. If you're from The Bahamas, and you're involved in the music scene, you will know Neil is an extraordinary percussionist. Neil has a mini-studio in his home in Stapledon and, for some reason, he let me in and taught me how to produce mini-records, or minisongs. And I became a rap and reggae music producer, which some of you may find strange, but I promise you, I was pretty good known as Daddy Q.

We'll move on from there. Some of you will have heard that before. But at the same time that I was learning to produce in a ministudio, I was also a member of the Bahamas National Youth Choir, founded and directed by our illustrious Mr. Adderley on the end here. It was sort of an awakening for me to different possibilities in music. Because I have a big mouth, and have always had a big mouth, Cleophas Adderley chose to ask me to sing some solos in the National Youth Choir. Singing a solo in the National Youth Choir is a fairly big deal when you're however old I was. It's a fairly big deal, period; because it's not an easy thing to do. And one day we were sitting around at practice at St. Johns - he probably doesn't remember this but I do. He 
was writing a song, "Conch Man, Fish Man". He actually asked the choir to help him write the song, which, for me, was a worldchanging sort of experience. It seemed simple. You're writing a song, so you say to the people who are around you, who you know to be creative, "Help me with this song", "What do you think we should say here?" or "What about this phrase? What should that say?" For me, that was my entry into thinking about myself as a composer as opposed to a songwriter or midi producer. My wife has never even heard this so this is news to her, too.

Then, when I decided to go back to school because ... I came to COB in 1988 and decided that I would do my father's bidding and major in biochem because he wanted me to be a doctor or a lawyer. Of course I hated it ... and so subsequently never went to class, ever. You chuckle but I'm serious ... So, after two years, it was clear that COB was not the experience that I needed at the time so I left and went out into the world to have fun and pursue my life. I was a DJ. I was an accounts clerk in a church. I sold clothes. I worked in a bank for a short while. So, I did a whole ton of stuff and finally decided that I would go back to school and get a degree in broadcast journalism. Because I started a degree in broadcast journalism at some point during that time, and Suzette said to me - we were dating at the time - but this is how I knew she was the right one. She said to me, practically on the eve of my going back to school - I had been accepted at a couple of colleges and decided to go to a Christian school called Oral Roberts University. I was going to major in broadcast journalism and Suzette said to me a month before I was supposed to go, "You know, you should study music." When she said that, I said, "Yes! I shall study music! For this is who I am!" And those of you who know me, you know that she was absolutely right. This is exactly what I was supposed to be. It was like a light turned on in my head. And so I quickly called the school and said, "Hey, I would like to switch my intended major and major in classical guitar" (having never played classical guitar). Having never played any guitar. So I show up for my audition and the guy says, "Ok Mr. Parker play me some scales."

"Sorry sir, I can't do that."

"Mr. Parker play me some arpeggios. Let's get started and you can warm up there."

"I'm sorry sir. What's an arpeggio?" So he looks at me and he says, "Quincy Parker?"

"Yes sir."

"Do you want to major in classical guitar?"

"Yes sir."

"Do you play guitar?"

"No sir."

"Any kind of guitar?"

"No sir."

"But you want to major in classical guitar?"

"Yes sir."

"Are you serious?"

"Yes sir."

So he paused for about 30 seconds and kind of looked at me and he said, "Ok". Now he should've been fired for doing that. Because there's no way you're supposed to let somebody like me in but luckily for him and for me, it turned out that I was talented. It wasn't about the money ... because I was on a scholarship. I had a full academic, well not a full academic scholarship, but an academic scholarship. So it wasn't all about the money.

Somebody spoke in his ear and he said, "Ok this is crazy but we will let this dude in."

Six months later, I was playing out as a side man on his professional gigs. So it turned out that I was a pretty decent guitar player, having 
never played guitar. So Suzette was right when she directed me to music and, after a while, I played jazz guitar and, of course, jazz is all about improvisation and that led me to composition. So, after my first semester I changed from classical guitar to majoring in composition and that was kind of when I really found what my calling was as a musician.

For the first two years of my degree, I wrote choral music. As you were walking in and being seated, you were listening to things like "Jerry Roker" and "Brown Skin Ga"l and some of the stuff that Cleophas did with the Bahamas National Youth Choir. For the first two years of my life as a composer, that was what I was hearing in my head as I was trying to write.

So my choral style - we will play one of my choral pieces in a little bit - is very much influenced by Cleophas. He may not know this, or he may hate the fact that I named him as one of my influences when you hear my music, but it's true. And it sort of brings for me the question of influences and heritage and culture into a very fine image because the question is, "Does my Bahamian-ness.. is it reflected in my music? Is it reflected in the music that I write?" And when you hear the piece that I will play for you first, which is called, "I Heard the Bells on Christmas Day", the answer to that question ... Well, I will leave you to judge. After we play a little bit of this I want to talk about what it is to have your culture reflected in your music and what that means to me.

This is a performance by the Bel Canto Singers. That's our nod to the classics. Now we change things a little bit. We can talk about the famous practice. So the beginning of that piece is kind of nebulous, then you have a very simple statement of the theme. Then we start to mess around with it a bit and have fun.
One of the things that I find fascinating about the question of Bahamian heritage as a composer is that it didn't sound anything like calypso or Junkanoo. Did it sound Bahamian at all to any of you? Anyone? No? I see one person saying yes and that person is a notorious rabble-rouser.

The next piece I'll play ... I'll play the next piece real quick because I'm running out of time. This next piece is from a film score that I wrote for a movie by a young man named Rupert Missick, Jr. The name of the movie is, The Kindly Ones, and the theme is a waltz written for one of the main characters. Close your eyes and ears, please. And the name of the tune is "The Bitches' Waltz". Yes, this is a performance of that waltz by the $\mathrm{C}$ Force ensemble in St. Croix.

I think that's enough for you to get the idea. Again, I don't know that I would say it quote, end quote, sounds Bahamian but to me. The question of nationality and identity, and the way they are reflected in music, is a wide open question. Because when you listen to art music, for example American composers, many of their greatest compositions borrow from traditions that are far removed from their own. They quote Wolfe who is a German composer, who himself quoted oriental sounds from time to time. This question of national identity and whether it is reflected in your music is, I think, at best, an open proposition. For me, the way I see it, if I wrote it, it's Bahamian. Because I'm a Bahamian; and whatever I write, by virtue of the fact that I wrote it, is Bahamian. Whether it's influenced by other things is up for grabs. My major influences as an instrumental composer runs the gamut from Camille SaintSaens, one of the great French composers, to some of the Chinese composers, to some African polyrhythm drumming and some other things. So I was not influenced by goombay or by Junkanoo or by soca or by 
calypso that I can tell. But I think it's that last phrase that is important. I can't tell how I was influenced by that music. All I know is, as a composer, the way I write is the way I write, and it comes out how it comes out. I like it. And that's the first test it has to pass, whether I like it or not. If I don't like it, it never sees the light of day; and if I do like it, then you're gonna have to suffer through it as much as you can. Thank you very much for your time.

\section{Christian Justilien}

Good morning. Good morning. My experience is quite different from Quincy's. I'm going to start at the very beginning. I grew up in a little settlement called Pinder's Point in Grand Bahama. My dad, Esterlus Justilien, was a Baptist minister who migrated to The Bahamas in the 50's from Haiti. It was quite interesting growing up in that kind of setting, in an isolated environment where there were only just a few houses in the yard and a mixed culture. We had some folks from Jamaica living right next door to us, and the Pinders and the Coopers right up the street. It was a unique blend of people. Just to put things in context, before Independence, I believe for the most part, anyone who was a Negro in The Bahamas was regarded the same. There was no difference between us. Not until ' 73 did we start to really take note of our cultural differences.

We often ate from the same pot, and you know at that time, in The Bahamas, each adult would be responsible for the raising of every child in the area. Discipline could be carried out by anyone. It was that kind of community. We all learned from each other, we all went to the same school, we all walked from school together - it was a wonderful and carefree time.

Now being involved in church, there was an organ in the church, one of those old pump organs. You had to pump the pedal and play at the same time. Now, that was a real balancing act. It became a real challenge for my dad to keep me out of that church. In fact, if I had to squeeze through the window to get in, I found a way in getting to that organ just to make some music.

I was about four or five years old when my older brother, George, introduced me to the guitar. Never seen this instrument before. It just fascinated me, the sounds, the chords and tones you could get outta this instrument. Now I particularly gravitated to the guitar early on because, to be quite honest with you, all the girls in Lewis Yard Primary School would gather around to hear me play and sing. Whenever I took the guitar to school, man, I was the rock star. Eventually my mom, Normilia, bought me my very own guitar on one of her many trips to Miami. That $\$ 12$ instrument was the beginning of my love affair with music. One of the major turning points in my life was when I went to school in the United States. At the age of 12, my parents sought to send us off to school in the States because they figured that we would get a better education at the time. I ended up at Miami Edison Junior High School and, subsequently, the Senior High School where I was exposed to bands for the first time. It was absolutely fascinating.

At Miami Edison I remember the band director asking me, "What instrument would you like to play?" I said, "I'd like to play the trumpet." 'Cause, you know, growing up in a small settlement like Pinder's Point and going to church, the only instrument you'd hear or read about in the Bible is Gabriel blow your what? Your trumpet. They ain't had nothin' 'bout no baritone or no saxophone or no clarinet or flute. I ain't never hear 'bout dem tings in the Bible. So I wanted to play the trumpet. Unfortunately, he had just given away the last trumpet. And he said, "Well, young man, we don't have any more trumpets. You gonna have to use the euphonium." And 
I said "Ok."

Now, I'm 12, and you know, I'm pretty big now, but at the age of 12 I was skinny. They used to call me spaghetti. I was a li'l small fella and the band director went into the instrument room and pulled out this big rusty horn. I mean this horn look like ain't no one bother with it for 'bout one 20 years. So I'm stuck with this big horn. In the case, it's almost as big as me. And you know they insist that you practice four hours a day. I had to take this on the bus every single day. I was so determined to be good at this instrument; I did what I had to do.

Now while I was at the junior high school, the marching band from the senior high school used to march past the junior high school every afternoon. And man, that was like, "I wanna be in that."

As soon as I went to the senior high school, I auditioned for the band, made it in and I made it in the second chair as assistant section leader. And there were about five or six baritone players. To make it in from the junior high school to second chair is pretty impressive. So that will tell you how much work I had put into my instrument in Grades 7 and 8. Fast-forward ... While I was at the senior high school, in Grade 10, a friend of my mother's worked at what I believe was called The Oceanus Hotel in Freeport. It was a hotel on the Lucaya Beach strip. There in the attic of the hotel he found a violin, and he took it to my mom and said, "Listen, I know your son likes music. Give this instrument to him." So she sent it to Miami for me. The instrument was not in working condition at the time. However, I took the violin to the orchestra director at the senior high school, Mr. Josef Mészáros, a gentleman originally from Hungary. It was missing I believe a bridge, a peg, needed to be re-stringed and so on. He took the instrument, had it repaired for me and gave it to me and said, "Listen, would you like to join the orchestra?" I said "Sure." So I joined the school orchestra.

After one year of playing in the school's orchestra, I auditioned for the Dade County Honors Orchestra and was selected from hundreds of young players. It was amazing that I made the Honors Orchestra. I was the first student from the Miami Edison Senior High School to make that orchestra in over 50 years at that time. So it was a big deal for the school as well as for me, because I had only been playing a short time.

I remember sitting in that orchestra on that first day. The conductor was Lt. Col. Gabriel $^{4}$, a military bandsman. He came to the podium with his baton and, because we had all got the music beforehand, we were well prepared. This is my first time. Remember, this is a li'l fella coming from Pinder's Point sitting in an orchestra of 100 plus persons. I'm sitting in the second violin section and he raised the baton and we are getting ready to play the first piece. As soon as that baton comes down ... BOOM! I hear this sound that I've never heard before. I literally froze up. I couldn't play because it was so beautiful. The sound was so amazing. And I just had to stop and look around, I could remember thinking, "How did you get here?" You know it was just unbelievable.

This experience prompted me to get into and just listen to all types of music. My repertoire expanded to jazz, classical, symphonic, marching band, etc. I'm influenced by people like John Philip Sousa, Henry Filmore, Mantovani, Debussy, and an endless list of composers from around the globe. I'm influenced by all of the great classical composers as well as musicians that perform various styles including jazz, Latin,

\footnotetext{
${ }^{4}$ Lt. Colonel Arnald D. Gabriel was the conductor of the United States Air Force Band and Orchestra, Washington, D.C. until his retirement in 1985.
} 
Caribbean, etc. The exposure to all of this music helped to shape my life and character in so many ways.

One of the things that I believe that helped me a lot in being accepting of all of this music is the fact that being from two cultures, Haitian and Bahamian, you get a unique perspective of what the transportation of African slaves to this new world has had on us, because I'm hearing songs at church in Creole, and I'm hearing them when I go to First Baptist Church in English. And I'm thinking to myself, "These are the same songs. How did this happen?" I'm hearing songs when I travel to Europe or the rest of the Caribbean and I'm seeing things that connect us all together. We are indeed family. This is a very, very small world and a lot of the traditions were spread by missionaries, or they came from one place, or a combination of the two. I believe that this experience is where my music has its roots.

I draw from both cultures; I draw from the training that I've had; I draw from my own personal experiences. This wonderful tapestry is what makes me who I am.

Most of you who know me know that I'm heavily involved in Junkanoo. I'm really involved in Junkanoo for one reason and one reason only. Not because it's the easiest music in the world, 'cause it is very, very complicated if you pay careful attention to it. It takes a lot of discipline if you want to do it right. It takes a lot of time and it's a lot of hard work especially in developing the many aspects such as dance, costuming, and music. I'm heavily involved because of the opportunity to work with the youth. I like to see when that bulb just lights up. When they get it. When they get a piece of music or something that they didn't like or something that they didn't understand and all of a sudden, they get it. That's amazing to me.

Being in this environment in The Bahamas is very frustrating, to be quite honest with you, as a composer, because the radio station is really constantly blowing a lot of negative stuff at you and really one steady diet of a particular kind of music. So it doesn't lend itself to being creative. So you have to think outside of the box and you have to venture out in order to challenge yourself. I challenged myself about two years ago to write 100 songs in 100 days and this is the first song that I wrote out of those 100 songs ... The first one I called "Day 1", and so on... I named them by the order of the day on which I wrote them.

Now, those who are familiar with a lot of Bahamian music, a lot of tones or melodic progression in this piece are not usual. There are some unusual things and the chord progression is not your typical I-IV-V. So I'm forced to think outside the box, just to be different. I like being different. I enjoy being different.

I had the opportunity of working with Nicolette Bethel a few years ago on the "Shakespeare in Paradise" project. This was a really good experience for me because it forced me to write for an entire production as well as for singers. This experience also pushed my creativity in taking Shakespeare and putting it into a Bahamian context in some cases. Most of the pieces were short and used mostly for background scenes; they therefore had to have a unique sound based on the script. One I composed is called "Phantom 5". Many of the pieces were written as vocal accompaniment for live singers on stage as well. This piece was just the music to back up a singer on the stage.

I'm going to play just a little bit of some pieces here just to give you an idea. Can you play a little of "Da Bight" for me? Now this piece we performed last evening and it's really a picture of being on a beach, no one is around except you, and you're just thinking, "What am I going to do with my life? What is 
the next step?" The piano really represents a wave just going back and forth. It's a calm day on the island of Eleuthera, and the cedar trees are basking in the sun on Wemyss Bight beach.

I'm gonna go right to the next piece. "Tilla" is another original composition I wrote for the $\mathrm{C}$ Force. It is inspired by the simple harmonies, the rhythmic complexities, and the acoustic sound of the once-popular goombay style of The Bahamas.

Ok. So to me, music is the same as a painting. I'm painting with sound while a painter uses a canvas. I take an instrument, and play a combination of notes that is supposed to make you feel something. And those of us who learn to do this well, we know exactly which combination of notes we need for a particular outcome. I picture myself as a mad scientist - when I go into my studio to write, I have on my white long jacket, and I have these tubes with smoke coming out of it. Do you see it? That's how I see myself. And depending on what I pour into this, it's gonna go BOOM! Or its gonna go shhhhhhh. Stuff is gonna happen! And that is how I wanna affect my audience.

My life is a journey. If I had to paint the entire journey to you from the beginning to now, you would say: UNBELIEVABLE!

Thank you everyone.

\section{Audrey Dean-Wright}

I was born in the culturally rich area of Bain Town near to Kunta Butta. I don't know if anybody has heard that word before. Kunta Butta and Bain Town were where slaves settled after emancipation. Kunta Butta is now known as Black Village.

During my childhood, daughters and sons of slaves, older people, still lived in that area. My lullabies were actually the sound of goatskin drums on a Saturday night as some descendants of slaves gathered around a bonfire to celebrate their African heritage. The Jump-in Dance and Fire Dance were a part of the celebrations. I couldn't go to those celebrations because my mother was a Christian but I certainly could hear them or peep through the window. Hence, they had a great influence on my life.

Another lullaby that I had was my Uncle Beacham Coakley's playing ${ }^{5}$. He was a marvellous musician and the sound of his sixstring double bass was something I heard all the time. So, they are my earliest memories of music. Then, of course, once my mother found out that I had a gift for music, she sent me to the best there was, which would have been Clement Bethel, who was my mentor. Also Hilda Barrett ${ }^{6}$, my Aunt Hilda, had a great influence on me. She never really taught me but she, Aunt Hilda, influenced me greatly.

I believe that my compositions are inspirations from God, first of all. But besides that, my greatest inspiration is born out of my childhood and my environment. However, there are other things that have impacted my music. My travels - I've lived in different countries such as the United States, Haiti and Cuba, and have travelled to places such as Prague, Poland, London, and Russia. I went to the Manhattan School of Music, so I was in the midst of culture and worked with professors from Julliard because we shared professors. I had a lot of exposure.

However, my compositions are me. I do not sit and think "I'm going to write a piece." It just happens - I start writing and I close myself away and it flows. So, I'm not one of the long-winded ones; I don't need several weeks to complete a composition. That's just the way it is for me.

\footnotetext{
${ }^{5}$ Beacham Coakley and his Emerald Beach Hotel Orchestra.

${ }^{6}$ Hilda Barrett, neé Donaldson, 1927-2008.
} 
I am going to go right into my compositions. I found out something when I was asked to do this: that in a lot of my music, the goatskin drum that was so important in my childhood, seems to be the rhythms in many of my compositions. And it's an awakening for me today ... and I am going to look into it more deeply. So we are going to look at one of my choral pieces "Rise Up Children, Give Thanks". It's sung by the Southeast African American Collegiate Festival, a combination of historically black university choirs. I'm conducting them. In that you will hear the syncopation that is so important in Bahamian music. You'll hear some call-and-response between voices and you will also hear counter rhythms and a very small fugal section.

Thank you. So you see, in that composition, you can hear some of the musical devices that are used in Bahamian music and, of course, storytelling, which is such an important part of our culture. Children years ago waited for Grammy to tell them stories. One of the main stories was "sperit", or ghost stories. You didn't want to go to bed, but you still wanted to hear the story. Afterwards you needed your sister to sleep in the bed with you.

I started writing a lot of our folk-like pieces that tell a story because of the Bahamas National Children's Choir ${ }^{7}$. I am co-director and co-founder of that choir. Many times we would be looking for folk music but the sexual connotations sometimes found in the music were not suitable for the children and, hence, my writing of some of our folk music styles. "Sperit Song" is actually one of them. Again, in the chorus of this song, you will hear some of our drumming in the chorus. "Sperit Song" is sung by one of my favourite and most talented sopranos in the whole world - JoAnn DeVeaux-Callender,

\footnotetext{
${ }^{7}$ Originally known as the Bain's Town Children's Choir, the Bahamas National Children's Choir became a national entity in 1992.
}

accompanied by a very, very wonderful pianist, Lee Callender, her husband.

I do have my calm moments. I write things like "Waltz of the Flamingoes", which is taken from a book that I will be publishing very, very shortly with a flautist playing all of the pieces. So, that's coming up very shortly. It's nostalgic because I remember going to the Ardastra Gardens as a child and seeing the flamingoes dance. I'd never seen anything like that in my life. They actually danced so, hence, we have the "Waltz of the Flamingoes."

The first section is a stately waltz. Then, when they take flight, I make use of 16 th notes to show the flamingoes in flight. We'll skip a section and go to the last part; the piece is performed by Jill Austen ${ }^{8}$, a leading American flautist based in New York City.

As I said, I lived in many places. I spent three and a half years in Haiti. Haiti na ke muen. I get emotional. Haiti is in my heart. You cannot live in a place like Haiti and remain unchanged and when they had the earthquake in January 2010, I was devastated just like they were. And hence the piece, "Port au Prince Tombe" performed by one of my voice students, Lavanda Brown. There is a section "Ki kote timon? Where is my child?" Listen to the drum rhythm in the second section. And it's "Ki kote timon." Here is the drum rhythm in the second section. And Haitians know how to mourn. They weep and cry and wail, hence the opening "O Mon Dieu" "O my God", which represents a Haitian wail. If you attended a Haitian funeral and you did not wail or faint, it is considered "bad form" as it is felt that you did not care for the deceased.

Thank you. That's the tapestry of my music. Thank you so much!

\footnotetext{
${ }^{8}$ Jill Austen, flautist and visual artist, who was formerly a member of faculty at the College of The Bahamas. http://www.jillausten.com/MUSIC.html
} 


\section{Cleophas Adderley ${ }^{9}$}

Good afternoon ladies and gentlemen. I'm really shocked that I influenced Quincy Parker to write music. When he first came to The Bahamas National Youth Choir, the same jokester you see now, I saw then and I said to myself, "My God, this guy, can he ever be serious? He doesn't seem to realize the extent and depth of his talent." Well, I think he finally got it. But, actually, I'm delighted that I was able to influence you to write, Quincy. You were always very confident and very intelligent.

I've had a lot of influences in my music and aspired to write music myself. I came from a very musical family. My grandfather, the late R.M. Bailey, was, amongst other things, a choral conductor and he played the violin. $\mathrm{He}$ made sure that all of his children played a musical instrument and so I was taught piano at the age of 7 by my aunt. My mother, who was a very well-known church organist, didn't really have time to teach us. Well, with nine children, you can understand. So, her sister, Rosalie Bailey, who was a nurse, taught us the piano. Her other sister, Gladys Bailey, taught me the pipe organ. Well, they were my first lessons on those instruments from my family members.

Then of course, I went on to high school and came across a wonderful lady by the name of Marion St. George. We called her Micky. She was the music teacher at the Government High School. She laid a very strong foundation that has set me really up in music for the rest of my life. Some of the things we did in that class were college-level work. It

\footnotetext{
${ }^{9}$ See Gangelhoff, C., Gibson, R., \& Johnson, C. (2011). From classical to calyspo: An interview with Bahamian composer and conductor, Cleophas R. E. Adderley. The International Journal of Bahamian Studies, 17(1). https:// doi.org/10.15362/ijbs.v17i1.148
}

was just me and her by that time - it was Alevel work (London General Certificate of Education Advanced Level) so she was able to pour into me, literally, her musical self.

I started writing under her influence. My first work actually I wrote - well, I thought it was a serious work - at the age of 14 . It was called The Sleeping Dog. Oh Lord! I hide that music now. I continued to write, just kept on writing, writing. It's gonna get better I said, "Well it can't get worse than this" - and you will discover a style.

So I continued to write and by the time I reached fifth form, I was writing for the school choir. By the time I did A-levels, I was writing everything from string quartets to orchestral parts, you name it. So, she gave me a really strong foundation.

Then, at the age of 17, I joined the Nassau Renaissance Singers, which was conducted by the late E. Clement Bethel. He was a very strong influence on my musical life. He also taught me piano and he really encouraged me to write even more and also to not forget our national essence as Bahamians. At that time the country was moving towards independence.

I happened to hear the theme for his Sammie Swain folk opera. I didn't know Clement, well, I wasn't his student at the time. I just heard it. Years later after I became a member of his choir (I was still in high school doing A-levels), I happened to whisper to him, "You know I wrote some piano variations on your theme", 'cause I was afraid to tell him. He said, "What?! Oh come on. Come play it for us." There he was with his friends and his wife and they all drinkin' and smokin' and I'm sitting there at the piano nervous as hell excuse me - playing these piano variations that were very very difficult for me! I don't know what I was thinking!

Anyway, I just poured out my heart into this 
music and he really loved the music. I was so happy that later on in life, Lee Callender gave the first performance and then Paul Shaw, who is in the audience, also took up the piece and has performed it internationally. Both Paul and Lee have recorded it so I am very delighted about that.

When I write music, of course, I write music that's either classical or folk, or a combination of both. Certainly in the classical music I employ the European vocabulary of music and you music students, I'm sure you understand what I'm talking about when I use that terminology - various types of scales, diatonic, etc., harmonies, devices and forms. When I started writing music, I was greatly in love with the fugue. Oh, at the time I was taking organ lessons at Christ Church Cathedral, so everything was a fugue, a fugue, a fugue. I made use of a lot of those European devices. The passacaglia, how could I forget that?

Henry Moss' wife, I don't know if she's here, she always reminds me and laughs, "You are the only man in The Bahamas who ever wrote a passacaglia. In fact, you're probably the only person here who knows what it is."

So I use these devices but I also employ our folk tunes, even our folk tales for inspiration. Of course I draw heavily on our folk rhythms, which are largely Afro-Caribbean rhythms and our sometimes-unique instrumentation. Today we seem to use the goatskin drum less and less in our local music. Even in my own music, I must confess, I've substituted it with a tom tom or another drum because the goatskin loses pitch so easily. You have to constantly heat it up with fire. The tin tub bass, we hardly employ anymore and, again, I must confess, music I've written for that instrument is now played by a modern bass instrument, but it doesn't sound quite the same, even though it works. And of course our harmonies, which you find for instance, in our rhyming spirituals and rake ' $n$ scrape music and you know our rake 'n scrape music is music that comes from the quadrille. The quadrille is a European art form. We blended it with our rhythms and our various instruments so that the style of music is now completely different and we can really say it's our own. So much so, that we don't call it quadrille music anymore. In that music we use mainly the accordion, goatskin drum and a saw that's scraped with a metal object such as a screwdriver or dull knife. So I use these instruments in my music.

Sometimes I don't use them at all. I try to hint at them in the coloring of my music. For instance, there's a section of the mass that I wrote (Missa Caribe), where the harmonies are very close and they crescendo, decrescendo, crescendo, decrescendo. When Clement Bethel first heard that he said, "Oh my God! That sounds just like the accordion." I said, "You know what? You're right." I was sort of doing these things and imitating them subconsciously, because these are the sounds I hear around me with Bahamian folk musicians and folk artists.

Then of course, there are the nuances of The Bahamas and different things that strike you. In one of my songs that was performed last night, "Nassau Harbour", sung by soprano JoAnn Callender, I try to give the contrast between sailing into a very smooth - oh! and Christy Lee on the piano. Thank you very much Christy - I try to give the contrast of smooth sailing into a harbour but the idea is, this isn't any harbour so the bass has a syncopation while the upper parts have the undulating water to help create the idea of a ship sailing along very smoothly on clear Caribbean waters. Then, all of a sudden, it goes into this very rhythmic section depicting the straw market when even the language changes. So I make use of language as well. And the singer sings in Bahamian dialect: "Da woman in da market! Chile, she talking 
about. She t'ief my customer! She too biggity! Dat cudda been my straw hat did sell!"

All of that is to try to use local nuances and pull out as many elements of The Bahamas as I could. Of course, I extend that further to the Caribbean in the music. Also in that song, and in some of the other songs you will hear, I hope you hear, sounds that are the influences of the black experience. To be more specific, for instance jazz. I would use jazz chords and again syncopation.

Someone mentioned to me, "Sometimes some sections of your music sound like Gershwin." I said, "Well that's not a bad thing." Gershwin was writing about the black experience in the United States. I'm essentially trying to capture the black experience here and elsewhere, and inject it into my music ... while employing the European vocabulary of [classical] music at the same time.

So, in the classical realm, I have written music for solo voice - solo voice and piano, solo voice and drum. There's a piece I wrote called, "I Remember Grandma." It's a story I heard while traveling on our family islands. This old lady spoke about how she could remember her grandma. I don't know whether she was referring to her great grandmother or whoever. The woman of whom she spoke was either a very close descendant of a slave, or may have been a freed slave, in that she still wore a nose ring in her nose. I thought, "Oh my god! I don't know if this woman is making this up but I like this, I'm running with this." It really touched me; and so I wrote a song about that, "I Remember Grandma", and how she had this nose ring, and how old she was. I thought: "I cannot employ European instruments in this piece at all." It was just voice and drum, voice and drum.

Then there is my choral music. Those of you who had the opportunity to come to the concert last night would have heard my arrangement of a Bahamian folk tune "Big Bunch a Little Bunch". Unfortunately a lot of these things are dying out because the children don't sing them anymore. They don't play the ring games anymore. "Big Bunch a Little Bunch" is a very playful and quick Bahamian folk song. ${ }^{10}$

I've also done an arrangement of "One a' Twenty". We played that at school as kids but again, children here don't seem to play it anymore. There is another folk song (ring play) "A Wen' Down Da Road". 11 There are so many of them. In fact, I have a work that I call The Cari Classics and it was my idea of, well, I think I was coining a term, Caribbean classical music. So I called it, The Cari Classics. It consists of some 17 Bahamian folk songs arranged for chorus, in some cases double chorus with soprano and other soloists in it, drums. The whole idea was to try and preserve as many of our ringplays, children's games, as possible, hence The Cari Classics.

Also in choral music, I have been writing music in the folk style for the Bahamas National Youth Choir [and I must clarify that I'm not the oldest person up here on this panel]. I have been writing music, and I will say, for the Youth Choir, from when it first started, which was 30 years ago. A lot of the material I either get from folk songs and I arrange them, or I write music in the style of the folk songs, just trying to capture the essence of Bahamian life.

One of those pieces is called "Da Jitney". The whole idea is for the kids on stage singing to

\footnotetext{
${ }^{10}$ Adderley, C. R. E. (n.d.). Big bunch a little bunch. Milwaukee, WI: Hal Leonard. Inventory \#HL 08742757

${ }^{11}$ Adderley, C. R. E. (1999). Three Bahamian folk songs. Milwaukee, WI: Hal Leonard. Inventory \#HL 08741919 (A wen' down da road; Ol lady; One a' twenty)
} 
act like they are waiting impatiently for, then later board the jitney trying to get where they have to go:

When this jitney comin'? We late for work. Job hard to find, now. Musse gatta wait 'til da Rapture come, for one broke down bus. If today wasn't Friday, I'd call in sick, but, man, I een so fool, cuz da A-sue is due an' da light bill raise, an' today is payday.

Then it goes on and it talks about how bad the jitney driver driving, and how he gat everybody gern this way and that way. Then, at the end of it, it talks about how the person got on the wrong bus, and all the time they cussing out the driver for nothing! There are many songs of that niche that I write about the nature of things going on here in The Bahamas from a folk standpoint.

(Mr. Adderley is interrupted)

Mr. A: Yes?

Mr. Bethel: Can we just jump in one minute? We are winding down on the time; but I really would like us to hear your clips.

Mr. A: Well of course. I don't have a problem. I'll shut up.

Mr. B: I actually would like you to talk a little about the opera.

Mr. A: Am I supposed to do all of that in this one session? I can pick one? Ok I'll pick one. Let's listen to ... I've also written music ... I told you about the choral stuff and there's the mass, which we're going to listen to. There's of course organ music and piano music I've mentioned as well and orchestral music too but we're gonna listen to a bit of the mass, which is Missa Caribe.

I started writing this mass when I was in high school at Government High and finished it after I graduated. This segment is being performed by the Bahamas National Youth Choir, but the first performance of the mass was by the Nassau Renaissance Singers. At that time, it was conducted by Clement Bethel. This is the Bahamas National Youth Choir, no, this recording isn't, although they have recorded it. This is a mass choir of Historic Black Colleges and Universities in the United States with some of the members of the Bahamas National Youth Choir and The College of The Bahamas Concert Choir (it was called 105 Voices of History http://www.hbcuchoirs-105voh.com/). Yeah, I can't remember what that means but... historic black colleges. Can you play a bit of that please? This is "Sanctus" from Missa Caribe. Thank you very much.

In the next segment I'll play some portions from the opera, if you're around to hear it. Thank you very much ladies and gentlemen. 